\title{
Kinetic Study of a Bacterial Cellulose Production by Komagataeibacter Rhaeticus Using Coffee Grounds and Sugarcane Molasses
}

\author{
Karina Carvalho de Souza ${ }^{a}$ (1), Nicolas Mattos Trindade ${ }^{b}$, Júlia Didier Pedrosa de Amorim ${ }^{a}$ (D), \\ Helenise Almeida do Nascimento ${ }^{b}\left(\mathbb{1}\right.$, Andréa Fernanda Santana Costa ${ }^{\circledR}$, Mariana Alves Henrique ${ }^{a}($, \\ Viviane Fonseca Caetano ${ }^{b^{*}}$ (), Leonie Asfora Sarubbo ${ }^{d}$ (D), Glória Maria Vinhas ${ }^{b}$

\begin{abstract}
${ }^{a}$ Universidade Federal de Pernambuco (UFPE), Programa de Pós-Graduação em Ciências dos Materiais, Avenida Jornalista Aníbal Fernandes, Cidade Universitária, 50740-560, Recife, PE, Brasil

${ }^{b}$ Universidade Federal de Pernambuco (UFPE), Departamento de Engenharia Química, Avenida dos Economistas, Cidade Universitária, 50.740-590, Recife, PE, Brasil

${ }^{c}$ Universidade Federal de Pernambuco (UFPE), Centro Acadêmico do Agreste, Avenida Marielle Franco, s/n, Km 59, Nova Caruaru, 55014-900, Caruaru, PE, Brasil
\end{abstract} \\ ${ }^{d}$ Universidade Católica de Pernambuco (UNICAP), Rua do Príncipe, Boa Vista, 50050-900, Recife, PE, \\ Brasil
}

Received: September 29, 2020; Revised: January 18, 2021; Accepted: February 21, 2021

\begin{abstract}
Biotechnology can be used to convert waste into valuable products. In this context, there is bacterial cellulose (BC), a natural biopolymer that can be transformed into several useful materials, but its production is limited due to the high cost of the culture media used for its industrialization. In this work, BC was produced from the bacteria Komagataeibacter rhaeticus, using coffee grounds, sugarcane molasses and ethanol. The experiments were carried out under static conditions. The products were collected every $48 \mathrm{~h}$, with a total period of $240 \mathrm{~h}$. The maximum BC production $\left(11.08 \mathrm{~g} . \mathrm{L}^{-1}\right)$ was obtained in a culture medium supplemented with coffee powder, hydrolyzed cane molasses and the addition of $1 \%(\mathrm{v} / \mathrm{v})$ ethanol. The results show that the use of different carbon sources of the evaluated by-products are viable alternatives in reducing costs in $\mathrm{BC}$ production.
\end{abstract}

Keywords: Bacterial cellulose, Biopolymer, Coffee grounds, Komagataeibacter rhaeticus, Sugarcane molasses.

\section{Introduction}

Represented by the formula $\left(\mathrm{C}_{6} \mathrm{H}_{10} \mathrm{O}_{5}\right)_{\mathrm{n}}$, cellulose is a polysaccharide formed by $\beta$-D-glucopyranose units linked by $\beta-(1 \rightarrow 4)$ glycosidic bonds and can be found in different types of living organisms. When bacteria of the genus Komagataeibacter are grown under static conditions, they can excrete cellulose on the surface of the medium as a layer of jelly ${ }^{1-3}$. This non-toxic biopolymer has a high potential for liquid retention, an important property for medical and tissue engineering applications. Bacterial cellulose (BC) has characteristics similar to vegetable cellulose (VC). However, $\mathrm{BC}$ has different degrees of polymerization and means of production. $\mathrm{BC}$ fibers are more stable and more resistant due to their ultra-fine reticular structure, high crystallinity, high tensile strength, high elasticity and durability ${ }^{4-6}$.

Due to the excellent physical and chemical properties, the use of $\mathrm{BC}$ arouses great interest in various applications. Food packaging ${ }^{7}$, scaffolding engineering ${ }^{8}$, electronic devices ${ }^{9}$, textile industries ${ }^{10}$, and even artificial blood vessels ${ }^{11}$, as well as application in pharmaceuticals as a drug delivery system ${ }^{12}$

*e-mail: viviane_fc@yahoo.com.br and cosmetics industry ${ }^{13}$, are some of the many examples of possible $\mathrm{BC}$ applications on an industrial scale ${ }^{14}$. $\mathrm{BC}$ production can be carried out by several gram-negative bacteria, among which those belonging to the genus Gluconacetobacter xylinus stand out as the main producers in many studies for commercial purposes ${ }^{15}$. To make $\mathrm{BC}$ production more economically efficient, it is important to use other bacteria that appear as alternatives to optimize production time, reduce costs and generate products with similar physicochemical properties. In this context, the bacterium Komagataeibacter rhaeticus appears as a viable alternative ${ }^{16}$.

Another aspect related to the high cost of production refers to the culture medium used in the process. Different sources of carbon, such as mannitol, sorbitol, fructose, glycerol, among others, can be used by the bacterium Komagataeibacteria rhaeticus. However, glucose is the most common, as it is the main source used in the standard production medium Hestrin \& Schramm ${ }^{17}$. In literature, studies have found alternative carbon sources, such as sugarcane molasses ${ }^{16}$, by-products from the biodiesel industry and residues from the confectionery industries ${ }^{18}$ and tropical fruit residues ${ }^{19}$. 
Among these alternatives, there is the combination of sugarcane molasses and coffee grounds as alternative carbon sources. Cane molasses is a by-product of sugar production and has large amounts of fermentable sugars such as fructose, sucrose and glucose $\mathrm{e}^{20}$. In addition, Brazil is the largest producer of sugarcane and sugar in the world, and is among the largest exporters of this product ${ }^{21}$. In relation to coffee, due to its huge production and consumption on a global scale, a considerable amount of coffee grounds powder residues is generated, which are harmful to the environment ${ }^{22}$. The use of this residue in the production of a biopolymer would help to reduce environmental pollution, in addition to promoting new alternatives to take advantage of its high organic content.

In this context, the present study aimed to produce bacterial cellulose films using a medium composed of nutritious and low-cost sources, such as sugarcane molasses (SCM) and coffee grounds (CG), and determine the kinetic parameters met in the process.

\section{Materials and Methods}

\subsection{Preparation of lineage keeping and inoculum medium}

The microorganism used was Komagataeibacter rhaeticus, isolated in the Microbiology Laboratory of the Department of Chemical Engineering at UFPE, and identified in the Microorganism Collection sector - UFPEDA (UFPE). The medium used to maintain the inoculum was a modified Hestrin and Schramm ${ }^{17}$ : Yeast Extract (5.0 g.L L $\left.^{-1}\right)$, Peptone (5.0 g.L L $\left.^{-1}\right)$, $\mathrm{Na}_{2} \mathrm{HPO}_{4}\left(2.7\right.$ g.L $\left.\mathrm{L}^{-1}\right)$, Citric Acid Monohydrate (1.15 g.L $\left.\mathrm{L}^{-1}\right)$, Agar-Agar (20.05 g.L.-1) and SCM as the main carbon source (40 g. $\mathrm{L}^{-1}$ ). The $\mathrm{pH}$ of the medium was adjusted to 6.0 .

\subsection{Inoculum preparation}

The medium prepared for the inoculum growth was $250 \mathrm{~mL}$ according to Hestrin \& Schramm ${ }^{17}$, where the carbon source was modified: Yeast Extract (5.0 g.L $\left.\mathrm{L}^{-1}\right)$, Peptone (5.0 g.L $\left.\mathrm{L}^{-1}\right)$, $\mathrm{Na}_{2} \mathrm{HPO}_{4}\left(2.7\right.$ g.L $\left.\mathrm{L}^{-1}\right)$, Citric Acid Monohydrate (1.15 g.L $\left.\mathrm{L}^{-1}\right)$ and SCM was used as the main carbon source $\left(40\right.$ g.L $\left.\mathrm{L}^{-1}\right)$. After adjusting the $\mathrm{pH}$ (6.0) using sodium hydroxide/hydrochloric acid, the medium was transferred to a $500 \mathrm{~mL}$ Erlenmeyer to be sterilized in an autoclave at $121^{\circ} \mathrm{C}$ for $15 \mathrm{~min}$. After the cooling process, 0.6 g.L.- $\mathrm{L}^{-1}$ of Komagataeibacter Rhaeticus cells were aseptically transferred to the inoculum in a shaker at $30^{\circ} \mathrm{C}$ for 2 days with a rotation speed of $120 \mathrm{rpm}$.

\subsection{Bacterial cellulose production}

Three culture media called (A), (A1), (B), (B1), (C) and (C1) were prepared. They consist of the following components: $\mathrm{CG}$ (8 g.L L $\left.^{-1}\right)$ and crude SCM (150 g.L.L $\left.{ }^{-1}\right)$; crude SCM (150 g.L.' ${ }^{-1}$; CG (8 g.L L $\left.^{-1}\right)$ and hydrolyzed SCM (150 g.L $\left.\mathrm{L}^{-1}\right)$; hydrolyzed SCM (150 g.L - $\left.^{-1}\right)$; CG (8 g.L -1 $^{-1}$, hydrolyzed SCM (150 g.L L $\left.^{-1}\right)$ and $1 \% \mathrm{v} / \mathrm{v}$ ethanol; and hydrolyzed SCM $\left(150\right.$ g.L $\left.\mathrm{L}^{-1}\right)$ and $1 \% \mathrm{v} / \mathrm{v}$ ethanol, respectively.

In culture medium (A) preparation, $4 \mathrm{~g}$ of SCM dissolved in $500 \mathrm{ml}$ of distilled water and $75 \mathrm{~g}$ of CG dispersed in $500 \mathrm{ml}$ of distilled water were mixed. The total volume of the culture medium was 1 liter. The $\mathrm{pH}$ of this medium was adjusted to 4.0 using a $1 \mathrm{M} \mathrm{HCl}$ solution. This culture medium was distributed to 5 Roux flasks. $90 \mathrm{ml}$ of the culture medium was transferred to each flask. These flasks were closed and sterilized in an autoclave at $121^{\circ} \mathrm{C}$ for $15 \mathrm{~min}$. After cooling the culture media, $10 \mathrm{~mL}$ of inoculum was transferred to each Roux flask. Culture medium (A) final volume, in each Roux flask, was $100 \mathrm{ml}$. The flasks were incubated in a static system for 240 hours. The bacterial cellulose films produced were collected every $48 \mathrm{~h}$, purified and weighed.

Culture media (B) and (C), have a similar procedure to the preparation of culture medium A, except with the prehydrolysis stage of sucrose present in sugarcane molasses. For culture media B and C preparation, the hydrolysis of sucrose present in cane molasses was carried out. For this, $4 \mathrm{~g}$ of cane molasses was dissolved in $500 \mathrm{~mL}$ of distilled water. The $\mathrm{pH}$ of this mixture was adjusted to 2.0 using a $1 \mathrm{M} \mathrm{HCl}$ solution. This mixture was placed in a water bath at $67^{\circ} \mathrm{C}$ for $15 \mathrm{~min}$. Upon completion of hydrolysis, the $\mathrm{CG}$ dispersed in $500 \mathrm{~mL}$ of distilled water was added. Culture medium total volume was 1 liter. The $\mathrm{pH}$ of this medium was adjusted to 4.0 using a $1 \mathrm{M} \mathrm{HCl}$ solution. This culture medium was distributed to 5 Roux flasks and $90 \mathrm{ml}$ was transferred to each flask. They were closed and sterilized in an autoclave at $121^{\circ} \mathrm{C}$ for $15 \mathrm{~min}$. After cooling the culture media, $10 \mathrm{~mL}$ of inoculum was transferred to each Roux flask. Culture medium (B) final volume in each Roux flask was $100 \mathrm{ml}$. For culture medium (C), $10 \mathrm{ml}$ of inoculum and then $1 \%$ ethanol in relation to the total volume $(100 \mathrm{ml})$ were added, which corresponds to $1 \mathrm{ml}$ of ethanol. Culture medium (C) final volume, in each Roux flask, was $101 \mathrm{~mL}$. The flasks were incubated in a static system for 240 hours. The bacterial cellulose films produced were collected every $48 \mathrm{~h}$, purified and weighed.

Culture media (A1), (B1) and (C1) were produced following the same methodology as culture media (A), (B) and $(\mathrm{C})$, with the difference that coffee grounds were not used in these media. The bacterial cellulose films produced in these systems were collected at the end of the $240 \mathrm{~h}$ period for weighing the biopolymer.

\subsection{Kinetics parameters}

The biopolymers produced were washed with distilled water and subjected to treatment with $0.1 \mathrm{M}$ sodium hydroxide $(\mathrm{NaOH})$ for $24 \mathrm{~h}$ at $80^{\circ} \mathrm{C}$ in a water bath, under static conditions, and then dried at $50{ }^{\circ} \mathrm{C}$ for 48 hours. To determine the substrate conversion factor in the product and the productivity, Equations 1 and $2^{23}$ were used, respectively.

$$
\begin{aligned}
& Y_{P / S}=\frac{P_{f}-P_{i}}{S_{i}-S_{f}} \\
& P R=\frac{P_{f}}{t}
\end{aligned}
$$

Where: $\mathrm{P}_{\mathrm{f}}$ is the final concentration of the product (g.L $\mathrm{L}^{-1}$ ); $\mathrm{P}_{\mathrm{i}}$ is the initial concentration of the product; $\mathrm{S}_{\mathrm{f}}$ is the final concentration of the substrate; $\mathrm{S}_{i}$ is the initial substrate concentration; $t$ is the total process time $(h) ; \mathrm{Y}_{\mathrm{P} / \mathrm{S}}$ is a conversion factor of the substrate in the product; and PR is productivity. The substrates (S) are the free monosaccharides (glucose 
and/ or fructose) in the culture medium. The product $(\mathrm{P})$ is bacterial cellulose. Time $(\mathrm{t})$ is the total production period (240 h).

The determination of total sugar reduction was performed using the DNS method (3,5-Dinitrosalicylic acid $)^{24}$. This method consists of reducing, in an alkaline medium, 3-amino5-nitrosalicylic acid (DNS) by the action of reducing sugars. To perform the quantification of hydrolysable sugars by the DNS method, the following steps were performed: $1 \mathrm{~mL}$ of molasses was hydrolyzed with $\mathrm{HCl}$ at $68^{\circ} \mathrm{C}$ for $15 \mathrm{~min}$; the solution was cooled and neutralized with $\mathrm{NaOH}$ and then diluted; of this solution, $0.5 \mathrm{~mL}$ was transferred to the Folin Wu tube and $1 \mathrm{ml}$ of DNS was added; this system was heated to $100^{\circ} \mathrm{C}$ for $5 \mathrm{~min}$; this solution was measured with distilled water to the total volume of $12.5 \mathrm{~mL}$ and the transmittance reading was performed on the Edutec model Q798DP UV-VIS spectrophotometer at a wavelength of $540 \mathrm{~nm}$.

\section{Results and Discussion}

\subsection{Kinetic study of the medium}

Table 1 shows the results of bacterial cellulose production with the following culture media evaluated: medium (A) (CG and crude SCM), medium (A1) (crude SCM), medium (B) (CG and hydrolyzed SCM), medium (B1) (hydrolyzed SCM), medium (C) (CG, hydrolyzed SCM and ethanol) and medium $(\mathrm{C} 1)$ (hydrolyzed SCM and ethanol) at various times.

Culture media (A) and (A1) showed the lowest bacterial cellulose production with or without the addition of SG. When compared with the other culture media evaluated, it appears that the hydrolyzed SCM, present in culture media (B), (B1), (C) and (C1), contributed to higher yields in the biopolymer production. This is justified by the fact that fermentable sugars contribute to increase cellulose production, which makes it important to carry out a process of hydrolysis in the disaccharide residues or other carbohydrates so that better cellulose yields are achieved ${ }^{25-27}$.

Culture medium (C) showed the highest bacterial cellulose production during the entire process $(240 \mathrm{~h})$. This is justified by the combination of hydrolyzed sucrose, coffee grounds and the addition of ethanol to the culture medium. CG is rich in polysaccharides, oils, proteins and substances that can also influence the production of bacterial cellulose $\mathrm{e}^{28,29}$. Ethanol, on the other hand, acts as an energy source for the generation of adenosine triphosphate (ATP) and increases the flow of glucose 6-phosphate (G6P) (precursor to BC) in the bacterial cellulose biosynthetic route. This solvent acts as an activator in cell growth and depending on the concentration may favor the production of bacterial cellulose ${ }^{28,30}$. This results in the effective use of glucose for the cellulose synthesis and not in its use for the acquisition of energy ${ }^{31}$. The great contribution of ethanol in the bacterial cellulose production can be seen in Figure 1, when graphically comparing the productions of biopolymer during the period from 0 to $240 \mathrm{~h}$ for culture media (A), (B) and (C). In the period of $240 \mathrm{~h}$, it appears that culture medium (C) had a biopolymer production 6 times greater than medium (A) and 4 times greater than culture medium (B).
Table 1. Monitoring the production of biopolymer in the culture media evaluated at various times.

\begin{tabular}{lcccccc}
\hline \multirow{2}{*}{$\begin{array}{c}\text { Produced } \\
\text { biopolymer (g.L }\end{array}$} & \multicolumn{7}{c}{ ) } & $\mathbf{0}$ & $\mathbf{4 8}$ & $\mathbf{9 6}$ & $\mathbf{1 4 4}$ & $\mathbf{1 9 2}$ & $\mathbf{2 4 0}$ \\
\hline Culture medium (A) & 0 & 0.61 & 1.13 & 1.30 & 1.76 & 1.79 \\
\hline Culture medium (A1) & 0 & - & - & - & - & 1.05 \\
\hline Culture medium (B) & 0 & 1.60 & 1.64 & 1.66 & 2.15 & 2.63 \\
\hline Culture medium (B1) & 0 & - & - & - & - & 1.70 \\
\hline Culture medium (C) & 0 & 4.33 & 7.20 & 8.08 & 8.89 & 11.08 \\
\hline Culture medium (C1) & 0 & - & - & - & - & 6.50 \\
\hline
\end{tabular}

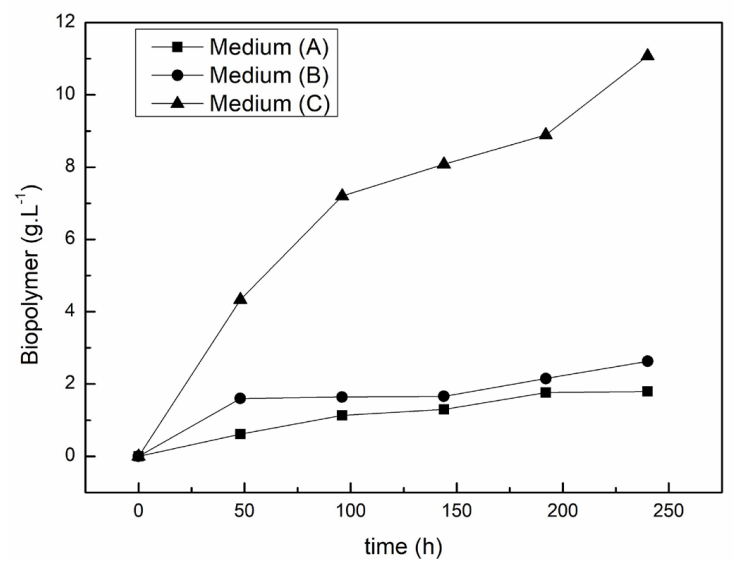

Figure 1. Production of bacterial cellulose as a function of the time for the culture media (A), (B) and (C).

Analyzing the contribution of coffee grounds in cellulose production, it appears that the nutrients present favored the production of bacterial cellulose. This can be verified by the yields in Table 1. Comparing the yields of culture medium (A) and (A1) in the total production period ( $240 \mathrm{~h})$, it can be seen that there was a $59 \%$ increase in bacterial cellulose yield. In relation to culture media (B) and (B1), there was a $65 \%$ increase in the bacterial cellulose production. Comparing the culture media $(\mathrm{C})$ and $(\mathrm{C} 1)$ that had the addition of ethanol, there was also a $59 \%$ increase in bacterial cellulose production.

The amount of CG that is generated worldwide is very high $^{32}$, which reinforces the importance of valuing this lowcost nutritional source in this polysaccharide production. In addition, $\mathrm{CG}$ can also be evaluated in other industrial bioprocesses. In literature, there are studies that used sugarcane molasses as a carbon source in bacterial cellulose production. No studies were found that used coffee grounds as a carbon source to produce bacterial cellulose.

Rodrigues et al. ${ }^{33}$ studied the production of bacterial nanocellulose using the bacteria Komagataeibacter $x y$ linus BPR 2001 and low-cost substrates such as molasses, ethanol, corn steep liquor (CSL) and ammonium sulfate. The results showed that the composition of molasses 5.38, CSL 1.91, ammonium sulfate 0.63 , disodium phosphate 0.270 , citric acid 0.115 and ethanol $1.38 \%(\mathrm{v} / \mathrm{v})$ result in a high yield of bacterial cellulose. Machado et al. ${ }^{20}$ studied the production of bacterial cellulose using the bacteria Komagataeibacter rhaeticus using sugarcane molasses (SCM) (totally or partially) without previous treatment, as an alternative carbon source. The membranes obtained showed characteristics similar to 
those obtained from conventional medium of Hestrin and Schramm and the partial substitution of glucose by the sources of nutrients present in the molasses (sucrose, fructose and glucose) do not affect the BC production capacity. Tyagi and Suresh ${ }^{34}$ studied the production of bacterial cellulose using Gluconacetobacter intermedius SNT-1 using acid-treated molasses. The results showed that the yields were relatively lower compared to the HS medium containing glucose as a carbon source. Bae and Shoda ${ }^{35}$ studied the production of bacterial cellulose by Acetobacter xylinum BPR2001 using SCM as a low-cost carbon source. The cane molasses was subjected to heat treatment with $\mathrm{H}_{2} \mathrm{SO}_{4}$. The results showed that the maximum $\mathrm{BC}$ concentration for this treated molasses increased $76 \%$ and the specific growth rate increased 2 times in comparison with that of non-hydrolyzed molasses.

Figures 2, 3 and 4 illustrate the kinetic profiles of the total reduction sugars (TRS) consumption versus the production of biopolymer during the period from 0 to $240 \mathrm{~h}$ for culture media (A), (B) and (C).

In Figures 2 and 3, it can be seen, from the curves, that the low production of bacterial cellulose is possibly due to the use of this carbon source for the formation of other noncellulosic metabolites. Without the presence of ethanol, glucose competes in cellulose synthesis and glucose oxidation ${ }^{36}$. In Figure 2, it is also observed that there is a stabilization of the polymer production curve after $192 \mathrm{~h}$. This may have been caused by the low amount of glucose and nutrients needed to produce $\mathrm{BC}$ after that time. In Figure 3, there is also a tendency towards this same behavior. However, it appears that in the interval of 192 to $240 \mathrm{hs}$, there is a stabilization of the amount of glucose, but the biopolymer production increases, showing that nutrients are still available in the culture medium. In the kinetic curve of Figure 4, it turns out that there was a shift in glucose consumption to BC biosynthesis. This can be verified by the production throughout the biosynthesis process. This was caused by ethanol that increases the flow of glucose-6-phosphate (G6P) in the metabolic pathway for $\mathrm{BC}$ synthesis and causes a reduction in glucose-6-phosphate dehydrogenase (G6PDH) activity, which causes inhibition of the pathway of phosphate pentoses ${ }^{37}$.

From Figures 2, 3 and 4 it was possible to determine the kinetic parameters, which are presented in Table 2.

The best result for the productivity parameter in this work was $0.046 \mathrm{~g} . \mathrm{L}^{-1} \cdot \mathrm{h}^{-1}$ for culture medium (C). However, when compared to the literature, other authors such as Bae and $\mathrm{Shoda}^{35}$, used SCM (40 g. $\left.\mathrm{L}^{-1}\right)$ treated with $\mathrm{H}_{2} \mathrm{SO}_{4}$ and reached a BC production of $0.074 \mathrm{~g} . \mathrm{L}^{-1} \cdot \mathrm{h}^{-1}$. Jaramillo et al. ${ }^{38}$, studied the effect of sucrose during the production of BC on static cultivation and obtained productivity of $0.0480 \mathrm{~g} . \mathrm{L}^{-1} \cdot \mathrm{h}^{-1}$ with a sucrose concentration of $1.7 \%(\mathrm{w} / \mathrm{v})$. In addition, Çakar et al. ${ }^{39}$, reported the improvement of BC production in a semi-continuous process in a medium containing SCMs and obtained a maximum production of $0.0024 \mathrm{~g} \cdot \mathrm{L}^{-1} \cdot \mathrm{h}^{-1} \mathrm{BC}$.

Therefore, it can be said that SCM enriched with CG in the presence of ethanol, contains many nutrients that are favorable to microbial growth, in addition to ethanol that acts as an enhancer for bacterial cellulose production. This shows that CG can be a promising and low-cost alternative for the biopolymer production.

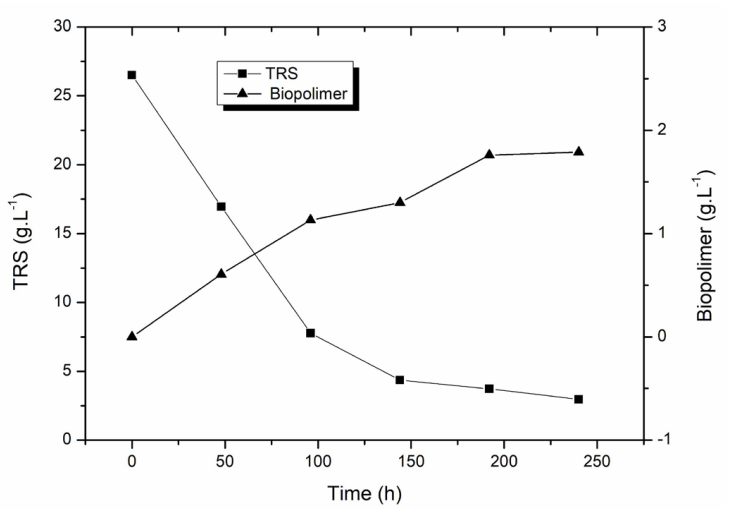

Figure 2. Kinetic curves based at the concentration of total reducing sugars for the culture medium (A).

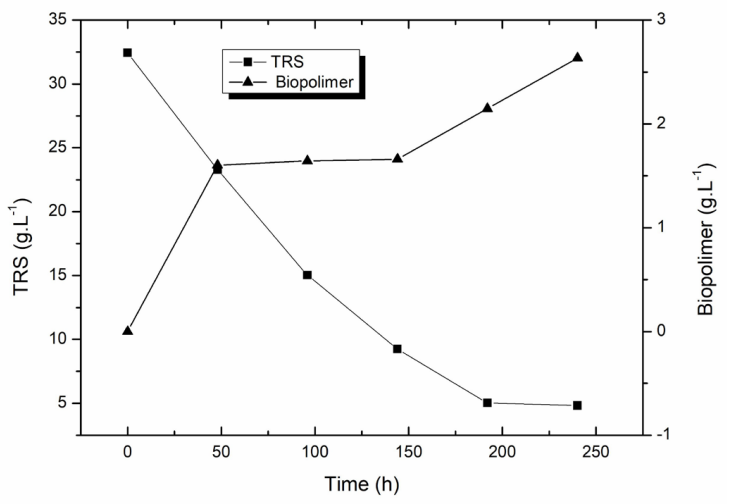

Figure 3. Kinetic curves based at the concentration of total reducing sugars for the medium (B).

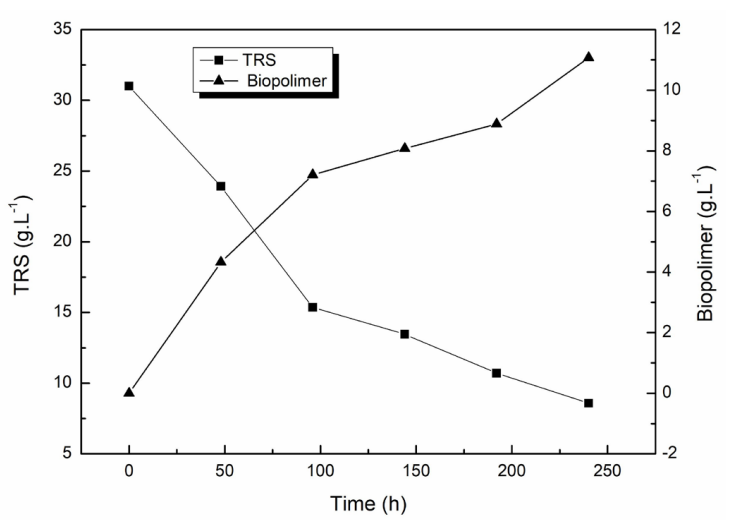

Figure 4. Kinetic curves based at the concentration of total reducing sugars for the culture medium (C).

Table 2. Results of the kinetic parameters of the culture media evaluated.

\begin{tabular}{cccc}
\hline \multirow{2}{*}{ Parameter } & \multicolumn{3}{c}{ Results } \\
\cline { 2 - 4 } & Medium (A) & Medium (B) & Medium (C) \\
\hline $\mathrm{Y}_{\mathrm{P} / \mathrm{S}}$ & 0.076 & 0.095 & 0.494 \\
\hline $\mathrm{PR}\left(\mathrm{g} \cdot \mathrm{L}^{-1} \cdot \mathrm{h}^{-1}\right)$ & 0.007 & 0.011 & 0.046 \\
\hline
\end{tabular}




\section{Conclusions}

The kinetic study of bacterial cellulose production using sugarcane molasses and coffee grounds was satisfactory. From the results, it was verified that sugarcane molasses hydrolysis increases in the biopolymer production. However, the combination of sugarcane molasses and coffee grounds provided extra nutrients to the medium, in addition to ethanol supplementation, showing that the synergistic action of these three components increases the production of bacterial cellulose. From this study, it was found that the addition of coffee grounds proved to be a valuable nutrient for the metabolism of BC production. It is believed that new studies on the topic are very promising since the production of $\mathrm{BC}$ in the presence of CG and SCM can still be optimized. Other factors of production can still be investigated, such as the maximum production time for the total conversion of the substrate into product and the use of batch fermentations.

\section{Acknowledgments}

The author Glória Maria Vinhas thanks the financial support of the Foundation of Support to Science and Technology of the State of Pernambuco. The author Viviane Fonseca Caetano thanks the financial support of FINEP through the ANP Human Resources Program for the Oil, Gas and Biofuels Sector (PRH 30.1-ANP). The author Karina Carvalho de Souza thanks the financial support of CAPES. The authors thank professor Dr. Olga Martins Marques (in memoriam) who taught us so much.

\section{References}

1. Machado RTA, Gutierrez J, Tercjak A, Trovatti E, Uahib FGM, Moreno GP, et al. Komagataeibacter rhaeticus as an alternative bacterium for cellulose production. Carbohydr Polym. 2016;152:841-9.

2. Son HJ, Heo MS, Kim YG, Lee SJ. Optimization of fermentation conditions for the production of bacterial cellulose by a newly isolated Acetobacter sp. A9 in shaking cultures. Biotechnol Appl Biochem Biotechnol. 2001;33:1-5.

3. Costa AFS, Nascimento VR, Amorim JDP, Gomes EAS, Sarubbo LA. Residue from the production of sugar cane: an alternative nutrient used in biocellulose production by gluconacetobacter hansenii. Chem Eng Trans. 2018;64:7-12.

4. Pircher N, Veigel S, Aigner N, Nedelec JM, Rosenau T, Liebner F. Reinforcement of bacterial cellulose aerogels with biocompatible polymers. Carbohydr Polym. 2014;111:505-13.

5. Silva CM, Bottene MK, Barud HGO, Barud HS, Ligabue RAJ, Vanusca DJ. Wettability and morphological characterization of a polymeric bacterial cellulose/corn starch membrane. Mater Res. 2015;18(2):109-13.

6. Moraes PRFS, Saska S, Barud H, Lima LR, Martins VCA, Plepis AMG, et al. Bacterial cellulose/collagen hydrogel for wound healing. Mater Res. 2016;19(1):106-16.

7. Albuquerque RM, Meira HM, Silva ID, Silva CJG, Almeida FCG, Amorim JDP, et al. Production of a bacterial cellulose/ poly(3-hydroxybutyrate) blend activated with clove essential oil for food packaging. Polym Polymer Compos. 2020

8. Unal S, Gunduz O, Uzun M. Tissue engineering applications of bacterial cellulose based nanofibers. In: Ahmed S, Ali W. Green nanomaterials. Advanced structured materials. USA: Springer; 2020. p. 126.

9. Guan F, Chen S, Sheng N, Chen Y, Yao J, Pei Q, et al. Mechanically robust reduced graphene oxide/bacterial cellulose film obtained via biosynthesis for flexible supercapacitor. Chem Eng J. 2019;360:829-37.

10. Fernandes M, Gama M, Dourado F, Souto AP. Development of novel bacterial cellulose composites for the textile and shoe industry. Microb Biotechnol. 2019;12:650-61.

11. Lee SE, Park YS. The role of bacterial cellulose in artificial blood vessels. Mol Cell Toxicol. 2017;13:257-61.

12. Ullah H, Badshah M, Correia A, Wahid F, Santos HA, Khan T. Functionalized bacterial cellulose microparticles for drug delivery in biomedical applications. Curr Pharm Des. 2019;25:3692-701.

13. Amorim JDP, Galdino CJ, Costa AFS, Sarubbo LA, Melo JFH. Avaliação do potencial da celulose bacteriana para aplicação em cosméticos. Brazilian Journal of Development. 2019;5:18457-62.

14. Wang J, Tavakoli J, Tang Y. Bacterial cellulose production, properties and applications with different culture methods $-\mathrm{A}$ review. Carbohydr Polym. 2019;219:63-76.

15. Azeredo HMC, Barud H, Farinas CS, Vasconcellos VM, Claro AM. Bacterial cellulose as a raw material for food and food packaging applications. Frontiers in Sustainable Food Systems. 2019;3(7):1-14

16. Machado RTA, Meneguin AB, Sábio RF, Franco DF, Antonio $\mathrm{SG}$, Gutierrez J, et al. Komagataeibacter rhaeticus grown in sugarcane molasses-supplemented culture medium as a strategy for enhancing bacterial cellulose production. Ind Crops Prod. 2018;122(15):637-46.

17. Hestrin S, Schramm M. Synthesis of cellulose by Acetobacterxylinum: II. Preparation of freeze - dried cells capable of polymerizing glucose to cellulose. Biochem J. 1954;58:345-52.

18. Tsouko E, Kourmentza C, Ladakis D, Kopsahelis N, Mandala L, Papanikolaou S, et al. Bacterial cellulose production from industrial waste and by-product streams. Jornal Internacional de Ciências Moleculares. 2015;16:14832-49.

19. Amorim J, Costa A, Galdino C, Vinhas G, Santos E, Sarubbo L. Bacterial cellulose production using industrial fruit residues as subtract to industrial application. Chem Eng Trans. 2019;74:1165-70.

20. Machado RTA, Meneguin AB, Sábio RM, Franco DF, Antonio $\mathrm{SG}$, Gutierrez J, et al. Komagataeibacter rhaeticus grown in sugarcane molasses-supplemented culture medium as a strategy for enhancing bacterial cellulose production. Ind Crops Prod. 2018;122:637-46.

21. Nachiluk K. Cana-de-açúcar: produção e processamento em 2019. Análises e Indicadores do Agronegócio. 2020;15(3):1-4.

22. Soares LS, Moris VAS, Yamaji FM, Paiva JMF. Utilização de resíduos de borra de café e serragem na moldagem de briquetes e avaliação de propriedades. Revista Materia. 2015;20(2):550-60.

23. Hiss H, Schmidell W, Lima UA, Aquarone E, Borzani W. Fermentation process kinetics. São Paulo: Edgard Blücher; 2001.

24. Miller GL. Use of dinitrosalicylle acid for determination of reducing sugar. Anal Chem. 1959;11:426-8.

25. Velasco-Bedran H, Lopez-Isunza F. The unified metabolism of Gluconacetobacter entanii in continuous and batch processes. Process Biochem. 2007;42:1180-90.

26. Mikkelsen D, Flanagan BM, Dykes GA, Gidley MJ. Influence of different carbon sources on bacterial cellulose production by Gluconacetobacter xylinus strain ATCC 53524. J Appl Microbiol. 2009; 107:576-83.

27. Tyagi N, Suresh S. Production of cellulose from sugarcane molasses using Gluconacetobacter intermedius SNT-1: optimization \& characterization. J Clean Prod. 2015;112:71-80.

28. Rani MU, Appaiah KAA. Production of bacterial cellulose by Gluconacetobacter hansenii UAC09 using coffee cherry husk. J Food Sci Technol. 2013;50(4):755-62.

29. Leifa F, Pandey A, Soccol CR. Solid state cultivation-an efficient method to use toxic agro-industrial residues. J Basic Microbiol. 2000;40:187-97. 
30. Naritomi T, Kouda T, Yano H, Yoshinaga F. Effect of ethanol on bacterial cellulose production from fructose in continuous culture. J Ferment Bioeng. 1998;85:598-603.

31. Ryngajłło M, Jacek P, Cielecka I, Kalinowska H, Bielecki S. Effect of ethanol supplement on the transcriptional landscape of bionanocellulose producer Komagataeibacter xylinus E25. Appl Microbiol Biotechnol. 2019;103(16):6673-88.

32. Mata TM, Martins AA, Caetano NS. Bio-refinery approach for spent coffee grounds valorization. Bioresour Technol. 2018;247:1077-84.

33. Rodrigues AC, Fontão AI, Coelho A, Leal M, Silva FAG, Wan $\mathrm{Y}$, et al. Response surface statistical optimization of bacterial nanocellulose fermentation in static culture using a low-cost medium. N Biotechnol. 2019;49:19-27.

34. Tyagi N, Suresh S. Production of cellulose from sugarcane molasses using Gluconacetobacter intermedius SNT-1: optimization \& characterization. J Clean Prod. 2016;112:71-80.

35. Bae S, Shoda M. Bacterial cellulose production by fedbatch fermentation in molasses medium. Biotechnol Prog. 2008;20:1366-71.
36. Rani MU, Appaiah KAA. Production of bacterial cellulose by Gluconacetobacter hansenii UAC09 using coffee cherry husk. J Food Sci Technol. 2011;50(4):755-62.

37. Li Y, Tian C, Tian H, Zhang J, He X, Ping W, et al. Improvement of bacterial cellulose production by manipulating the metabolic pathways in which ethanol and sodium citrate involved. Appl Microbiol Biotechnol. 2012;96:1479-87.

38. Jaramillo RL, Tobio WJ, Escamilla JM. Effect of sucrose in the production of cellulose by Gluconacetobacter xylinus in static culture. Rev Mvz Cordoba. 2012;17:3004-13.

39. Çakar F, Özer I, Aytekin AÖ, Sahin F. Improvement production of bacterial cellulose by semi-continuous process in molasses médium. Carbohydr Polym. 2014;106:7-13. 